\title{
$\begin{array}{lllllllll}\text { I } & \mathrm{N} & \mathrm{S} & \mathrm{T} & \mathrm{I} & \mathrm{T} & \mathrm{U} & \mathrm{T} & \mathrm{E}\end{array}$
}

\section{Over Sixteen Million Children in Poverty in 2011}

\author{
MARYBETH J. MATTINGLY, JESSICA A. BEAN, AND ANDREW SCHAEFER
}

$I^{n}$ $\mathrm{n}$ this brief, we use American Community Survey (ACS) data released on September 20, 2012 to address 2011 patterns of child poverty. ${ }^{1}$ Poverty determination is based on the U.S. Office of Management and Budget income thresholds, which vary by family size and composition. In 2011, the poverty line for a family of four (two adults, two children) was $\$ 22,811 .^{2}$ We focus on child poverty for three primary reasons: first, for well over three decades, children have been the age group most likely to live below the poverty line, with young children being particularly vulnerable. Second, children often benefit less than seniors from America's primary social safety net programs. ${ }^{3}$ Third, research consistently documents lasting impacts of child poverty across a wide range of health, educational, and occupational outcomes. These consequences are often worse for young children. ${ }^{4}$

We highlight changes in child (under age 18) poverty across states and by region and place type and in young child (under age 6) poverty by region and place type. ${ }^{5}$ We also show variation in child poverty across states, consider children living below 50 percent of the poverty line (defined here as "deep poverty," representing the most disadvantaged), and children who live under 200 percent of poverty, considered "low income" in this brief. We pay particular attention to these children given that the official poverty line may be an inadequate measure of need. In fact, according to the National Center on Child Poverty, it takes between 1.5 and 3.5 times the official poverty threshold for a typical family to meet its basic needs (depending on location). ${ }^{6}$ Throughout, we focus primarily on two time periods-change since 2007, as the nation entered the recession, and change over the past year.

\section{Child Poverty Through Age 18}

Table 1 shows national and regional child poverty numbers by place type, including the changes since 2007 and 2010 with statistically significant changes indicated in bold. ${ }^{7}$ Additionally, we present child poverty rates by state (see Appendix 1, page 6). In 2011 , the child poverty rate was 22.5 percent, up from 18.0 percent in 2007 and 21.6 percent in 2011. In addition, there is wide variation in child poverty rates by state and

* This brief has been updated to include revised versions of Figure 1 and Appendix 1.

\section{Key Findings}

- According to the American Community Survey, the overall child poverty rate for the United States rose slightly from 21.6 in 2010 to 22.5 percent in 2011 , resulting in an estimated 16.4 million children living in poverty. Of these children, 6.1 million are young (under age 6).

- $\quad$ Forty-five percent, or 32.7 million, of America's children reside in families with incomes below 200 percent of the poverty threshold.

- $\quad$ Since 2010, child poverty increased in all regions. In 2011, the South remained home to the greatest number (6.9 million) and the highest percentage (25.1 percent) of poor children.

- Nearly 30 percent of children in central cities and over one quarter of children in rural areas lived in poverty in 2011 , significantly higher than the 17.1 percent in suburban areas. Rates increased in all three of these place types since 2010.

- $\quad$ Over 7.3 million children (10.1 percent) lived in families with incomes below 50 percent of the federal poverty line, an increase from 8.0 percent since the Great Recession began, and an increase from 9.6 percent in 2010.

region, with the highest rates in the South and the lowest rates in the Northeast. The largest increase in child poverty from 2007 to 2011 was in central cities in the Midwest, while the largest one-year increase came in the rural West.

Children under age 18 are least often poor in suburban America, where rates are estimated at 17.1 percent nationally, as compared to 26.3 percent in rural areas and 29.5 percent in central cities. However, given the distribution of America's children, a higher number of poor children live in the suburbs (6.5 million), as compared to 3 million in rural places. Between 2010 and 2011, child poverty rose in nineteen states and fell in 


\section{CARSEY INSTITUTE}

\section{TABle 1. Child POVERTy By PLACE TYPE AND REgion IN 2011}

\begin{tabular}{|c|c|c|c|c|c|c|c|c|c|c|c|c|c|c|c|c|}
\hline \multicolumn{17}{|c|}{2011 AMERICAN COMMUNITY SURVEY } \\
\hline & \multicolumn{4}{|c|}{ ALL PLACE TYPES } & \multicolumn{4}{|c|}{\begin{tabular}{l|l} 
RURAL \\
\end{tabular}} & \multicolumn{4}{|c|}{ SUBURBAN } & \multicolumn{4}{|c|}{ CENTRAL CITY } \\
\hline & $\begin{array}{c}\text { Number } \\
\text { below } \\
\text { poverty }\end{array}$ & $\begin{array}{l}\text { Percent } \\
\text { below } \\
\text { poverty }\end{array}$ & $\begin{array}{c}\text { Percentage } \\
\text { Point Change } \\
\text { Since } 2010\end{array}$ & $\begin{array}{c}\text { Percentage } \\
\text { Point Change } \\
\text { Since } 2007\end{array}$ & $\begin{array}{c}\text { Number } \\
\text { below } \\
\text { poverty }\end{array}$ & $\begin{array}{l}\text { Percent } \\
\text { below } \\
\text { poverty }\end{array}$ & $\begin{array}{c}\text { Percentage } \\
\text { Point Change } \\
\text { Since } 2010\end{array}$ & $\begin{array}{c}\text { Percentage } \\
\text { Point Change } \\
\text { Since } 2007\end{array}$ & $\begin{array}{c}\text { Number } \\
\text { below } \\
\text { poverty }\end{array}$ & $\begin{array}{l}\text { Percent } \\
\text { below } \\
\text { poverty }\end{array}$ & $\begin{array}{c}\text { Percentage } \\
\text { Point Change } \\
\text { Since } 2010\end{array}$ & $\begin{array}{c}\text { Percentage } \\
\text { Point Change } \\
\text { Since } 2007\end{array}$ & $\begin{array}{c}\text { Number } \\
\text { below } \\
\text { poverty }\end{array}$ & $\begin{array}{l}\text { Percent } \\
\text { below } \\
\text { poverty }\end{array}$ & $\begin{array}{c}\text { Percentage } \\
\text { Point Change } \\
\text { Since } 2010\end{array}$ & $\begin{array}{c}\text { Percentage } \\
\text { Point Change } \\
\text { Since } 2007\end{array}$ \\
\hline United States & $16,400,000$ & 22.5 & 0.9 & 4.5 & $2,971,598$ & 26.3 & 0.9 & 4.4 & $6,551,820$ & 17.1 & 1.0 & 4.3 & $6,863,082$ & 29.5 & 0.8 & 4.9 \\
\hline Norheast & $2,257,692$ & 18.8 & 1.0 & 3.1 & 217,638 & 20.1 & 1.0 & 3.7 & 890,049 & 12.0 & 0.8 & 2.8 & $1,150,005$ & 32.8 & 1.3 & 4.3 \\
\hline Midwest & $3,353,167$ & 21.4 & 1.0 & 4.7 & 758,043 & 22.0 & 0.8 & 4.6 & $1,200,056$ & 15.2 & 1.1 & 4.2 & $1,395,068$ & 32.3 & 0.9 & 5.7 \\
\hline South & $6,889,861$ & 25.1 & 0.9 & 4.5 & $1,591,733$ & 31.1 & 0.6 & 4.3 & $2,800,303$ & 19.7 & 1.1 & 4.6 & $2,497,825$ & 30.6 & 0.5 & 4.2 \\
\hline West & $3,885,780$ & 22.1 & 1.0 & 5.2 & 404,184 & 24.5 & 1.9 & 4.3 & $1,661,412$ & 19.1 & 1.0 & 5.0 & $1,820,184$ & 25.0 & 0.7 & 5.5 \\
\hline
\end{tabular}

1. Levels of urbanization are defined as follows: rural consists of ACS geographic components "Not in metropolitan or micropolitan statistical area" and "in micropolitan statistical area"; suburban includes "In metropolitan statistical area-not in principal city" and central city includes "In metropolitan statistical area-in principal city.

2. Data are based on 2011 American Community Survey estimates. For corresponding margins of error, refer to the U.S. Census American Community Survey.

3. Percentage point changes are based on unrounded poverty percentages and may differ slightly from those that would be obtained using rounded figures.

4. Bold font indicates statistically significant differences $(p<0.05)$

\section{Figure 1. Percent of Children Below The POVERTy Line, 2011}

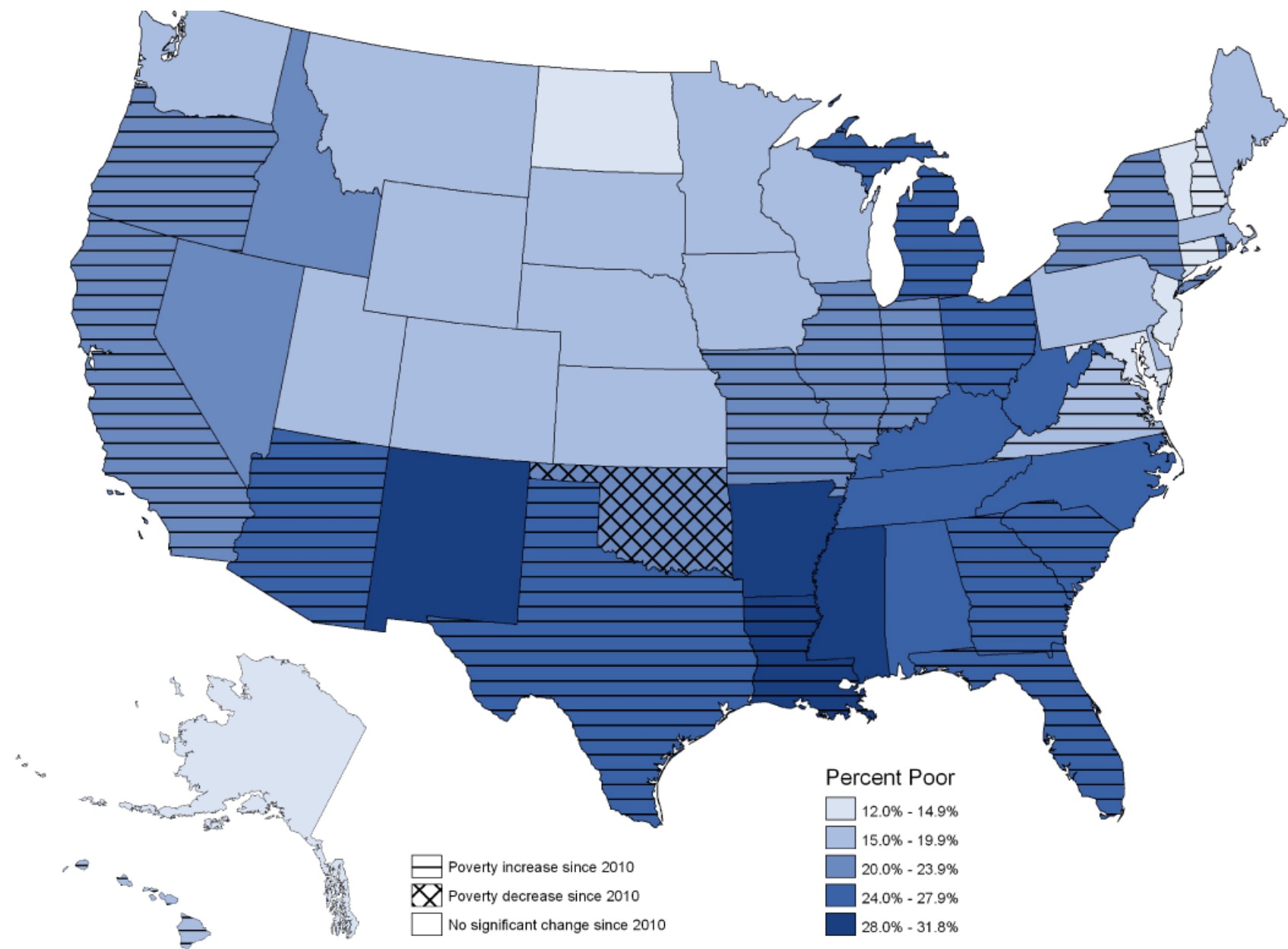


TABle 2. Young CHILd POVERTy By PLACE TYPe AND REgion IN 2011

\begin{tabular}{|c|c|c|c|c|c|c|c|c|c|c|c|c|c|c|c|c|}
\hline \multicolumn{17}{|c|}{2011 AMERICAN COMMUNITY SURVEY } \\
\hline & \multicolumn{4}{|c|}{ ALL PLACE TYPES } & \multicolumn{4}{|c|}{ RURAL } & \multicolumn{4}{|c|}{ SUBURBAN } & \multicolumn{4}{|c|}{ CENTRAL CITY } \\
\hline & $\begin{array}{c}\text { Number } \\
\text { below } \\
\text { poverty }\end{array}$ & $\begin{array}{l}\text { Percent } \\
\text { below } \\
\text { poverty }\end{array}$ & $\begin{array}{c}\text { Percentage } \\
\text { Point Change } \\
\text { Since } 2010\end{array}$ & $\begin{array}{c}\text { Percentage } \\
\text { Point Change } \\
\text { Since } 2007\end{array}$ & $\begin{array}{c}\text { Number } \\
\text { below } \\
\text { poverty }\end{array}$ & $\begin{array}{l}\text { Percent } \\
\text { below } \\
\text { poverty }\end{array}$ & $\begin{array}{c}\text { Percentage } \\
\text { Point Change } \\
\text { Since } 2010\end{array}$ & $\begin{array}{c}\text { Percentage } \\
\text { Point Change } \\
\text { Since } 2007\end{array}$ & $\begin{array}{c}\text { Number } \\
\text { below } \\
\text { poverty }\end{array}$ & $\begin{array}{l}\text { Percent } \\
\text { below } \\
\text { poverty }\end{array}$ & $\begin{array}{c}\text { Percentage } \\
\text { Point Change } \\
\text { Since } 2010\end{array}$ & $\begin{array}{c}\text { Percentage } \\
\text { Point Change } \\
\text { Since } 2007\end{array}$ & $\begin{array}{c}\text { Number } \\
\text { below } \\
\text { poverty }\end{array}$ & $\begin{array}{l}\text { Percent } \\
\text { below } \\
\text { poverty }\end{array}$ & $\begin{array}{c}\text { Percentage } \\
\text { Point Change } \\
\text { Since } 2010\end{array}$ & $\begin{array}{c}\text { Percentage } \\
\text { Point Change } \\
\text { Since } 2007\end{array}$ \\
\hline United States & $6,090,017$ & 25.6 & 0.8 & 5.0 & $1,117,736$ & 30.8 & 0.6 & 5.1 & $2,346,634$ & 19.7 & 1.0 & 4.9 & $2,625,647$ & 31.8 & 0.4 & 4.9 \\
\hline Northeast & 825,725 & 21.8 & 1.2 & 4.2 & 78,786 & 24.2 & 0.9 & 5.3 & 326,407 & 14.7 & 1.2 & 4.2 & 420,532 & 33.9 & 0.8 & 3.9 \\
\hline Midwest & $1,274,596$ & 25.2 & 1.1 & 5.9 & 291,561 & 26.6 & 0.7 & 5.5 & 430,906 & 17.9 & 1.3 & 5.0 & 552,129 & 35.5 & 1.1 & 6.9 \\
\hline South & $2,585,047$ & 28.4 & 0.6 & 4.7 & 590,358 & 35.7 & 0.2 & 4.6 & $1,006,755$ & 22.4 & 0.9 & 4.9 & 987,934 & 33.6 & 0.3 & 4.2 \\
\hline West & $1,404,649$ & 24.0 & 0.6 & 5.3 & 157,031 & 28.7 & 1.9 & 5.9 & 582,566 & 20.9 & 0.9 & 5.2 & 665,052 & 26.3 & -0.1 & 5.1 \\
\hline
\end{tabular}

1. Levels of urbanization are defined as follows: rural consists of ACS geographic components "Not in metropolitan or micropolitan statistical area" and "in micropolitan statistical area"; suburban includes "In metropolitan statistical area-not in principal city" and central city includes "In metropolitan statistical area-in principal city."

2. Data are based on 2011 American Community Survey estimates. For corresponding margins of error, refer to the U.S. Census American Community Survey.

3. Percentage point changes are based on unrounded poverty percentages and may differ slightly from those that would be obtained using rounded figures.

4. Bold font indicates statistically significant differences $(p<0.05)$.

one (Oklahoma) (see Figure 1 and Appendix 1). However, even in Oklahoma, rates remained significantly elevated from prerecession levels. All other places had rates that were unchanged or increased since 2010.

\section{Young Child Poverty}

Table 2 shows 2011 poverty estimates for children under age 6 , both nationally and regionally. Those under age 6 typically have the highest poverty rates, and children who are poor before age 6 have the most adverse outcomes later in life. ${ }^{8}$

As we did for all children in Table 1, we show estimates and the changes since 2007 and 2010 with statistically significant changes indicated in bold. In 2011, an estimated 25.6 percent of young children in America lived in families with incomes below the federal poverty threshold. Young child poverty increased in all place types and in all regions between 2010 and 2011, with the largest increases in the Northeast and in suburban areas. Young child poverty is highest in the South and lowest in the Northeast. In all regions, young child poverty is higher in central cities and rural places than in the suburbs.

\section{Deep Poverty}

In Table 3, we turn to patterns of deep poverty. Children are considered to be living in deep poverty if their family income is less than half the poverty threshold for their family type-in $2011, \$ 11,406$ for a family comprised of two adults and two children. Just over 10 percent of America's children, or more than 7.3 million, live in deep poverty, a significantly greater share than in 2010 and an increase from 8.0 percent in 2007. Deep poverty is highest in central cities (13.7 percent), followed by rural areas (11.6 percent), and lowest in the suburbs (7.4 percent); however, deep poverty rose slightly in all regions between 2010 and 2011. The South is home to the largest share of deeply poor children (11.2 percent, or 3.1 million children), with even higher rates in rural areas and central cities in the South (14.1 percent in both).

TABle 3. ChildReN IN DEEP POVERTY BY PLACE TYPE IN 2011

\begin{tabular}{|c|c|c|c|c|c|c|c|c|c|c|c|c|c|c|c|c|}
\hline \multicolumn{17}{|c|}{2011 AMERICAN COMMUNITY SURVEY } \\
\hline & \multicolumn{4}{|c|}{ ALL PLACE TYPES } & \multicolumn{4}{|c|}{ RURAL } & \multicolumn{4}{|c|}{ SUBURBAN } & \multicolumn{4}{|c|}{ CENTRAL CITY } \\
\hline & $\begin{array}{c}\text { Number } \\
\text { below } 50 \% \\
\text { of poverty }\end{array}$ & $\begin{array}{c}\text { Percent } \\
\text { below } 50 \% \\
\text { of poverty }\end{array}$ & $\begin{array}{c}\text { Percentage } \\
\text { Point } \\
\text { Change } \\
\text { Since } 2010\end{array}$ & $\begin{array}{c}\text { Percentage } \\
\text { Point } \\
\text { Change } \\
\text { Since 2007 }\end{array}$ & $\begin{array}{l}\text { Number } \\
\text { below } 50 \% \\
\text { of poverty }\end{array}$ & $\begin{array}{c}\text { Percent } \\
\text { below } 50 \% \\
\text { of poverty }\end{array}$ & $\begin{array}{l}\text { Percentage } \\
\text { Point } \\
\text { Change } \\
\text { Since } 2010\end{array}$ & $\begin{array}{c}\text { Percentage } \\
\text { Point } \\
\text { Change } \\
\text { Since } 2007\end{array}$ & $\begin{array}{c}\text { Number } \\
\text { below } 50 \% \\
\text { of poverty }\end{array}$ & $\begin{array}{c}\text { Percent } \\
\text { below } 50 \% \\
\text { of poverty }\end{array}$ & $\begin{array}{c}\text { Percentage } \\
\text { Point } \\
\text { Change } \\
\text { Since } 2010\end{array}$ & $\begin{array}{c}\text { Percentage } \\
\text { Point } \\
\text { Change } \\
\text { Since 2007 }\end{array}$ & $\begin{array}{l}\text { Number } \\
\text { below } 50 \% \\
\text { of poverty }\end{array}$ & $\begin{array}{c}\text { Percent } \\
\text { below } 50 \% \\
\text { of poverty }\end{array}$ & $\begin{array}{l}\text { Percentage } \\
\text { Point } \\
\text { Change } \\
\text { Since } 2010\end{array}$ & $\begin{array}{c}\text { Percentage } \\
\text { Point } \\
\text { Change } \\
\text { Since } 2007\end{array}$ \\
\hline United States & $7,335,997$ & 10.1 & 0.5 & 2.1 & $1,313,739$ & 11.6 & 0.5 & 2.0 & $2,823,457$ & 7.4 & 0.4 & 1.9 & $3,198,801$ & 13.7 & 0.5 & 2.6 \\
\hline Northeast & $1,044,959$ & 8.7 & 0.5 & 1.3 & 92,362 & 8.5 & 0.6 & 1.1 & 402,184 & 5.4 & -0.5 & 0.5 & 550,413 & 15.7 & 0.5 & 1.8 \\
\hline Midwest & $1,553,272$ & 9.9 & 0.7 & 2.2 & 330,917 & 9.6 & 0.7 & 2.1 & 524,489 & 6.6 & -0.9 & 0.8 & 697,866 & 16.1 & 1.1 & 2.9 \\
\hline South & $3,077,453$ & 11.2 & 0.4 & 2.2 & 723,213 & 14.1 & 0.4 & 2.2 & $1,200,981$ & 8.5 & -1.3 & 0.8 & $1,153,259$ & 14.1 & 0.3 & 2.4 \\
\hline West & $1,660,313$ & 9.4 & 0.3 & 2.5 & 167,247 & 10.1 & 0.5 & 2.0 & 695,803 & 8.0 & -1.2 & 0.9 & 797,263 & 11.0 & 0.3 & 3.0 \\
\hline
\end{tabular}

1. Levels of urbanization are defined as follows: rural consists of ACS geographic components "Not in metropolitan or micropolitan statistical area" and "in micropolitan statistical area"; suburban includes "In metropolitan statistical area-not in principal city" and central city includes "In metropolitan statistical area-in principal city."

2. Data are based on 2011 American Community Survey estimates. For corresponding margins of error, refer to the U.S. Census American Community Survey.

3. Percentage point changes are based on unrounded poverty percentages and may differ slightly from those that would be obtained using rounded figures.

4. Bold font indicates statistically significant differences $(p<0.05)$. 


\section{Low Income}

Our final analyses in this brief focus on children residing in families with incomes below 200 percent of the official poverty threshold. Given the low wage jobs that many in the bottom income quintile hold, it is useful to explore changes in the percent of children living in families who may be struggling to meet their daily needs, even if they are not below the poverty threshold.

Estimates from the ACS suggest that 45 percent, or 32.7 million, American children reside in homes with incomes below 200 percent of the federal poverty line. The South is home to the greatest number and highest rate of children living in such low income families, followed by the West, Midwest, and Northeast. All regions realized increases in the low-income child population since 2010, as did nine states (Alaska, California, Connecticut, Florida, Hawaii, Illinois, Nevada, New York, and North Carolina), while the District of Columbia saw a significant decline (by 6.5 percentage points). In no state, however, has there been a significant decline in the low-income population since the onset of the recession.

\section{Conclusion}

In the wake of the recession, child poverty remains high, presenting significant challenges for children's futures. Findings from the American Community Survey suggest the dramatic increases in deep poverty, poverty, and low-income families that have been observed since the onset of the Great Recession persist and, in some places, continue to grow.

In addition to the sustained high rates of child poverty, our analyses of the American Community Survey suggest that over one in ten children live in homes with incomes below half the poverty threshold. This is particularly troubling as evidence shows there are lasting implications of growing up in such deeply poor environments. For example, while children living in poor households score worse on educational outcomes than non-poor children, those living in deep poverty score worst of all on cognitive tests. ${ }^{9}$

Finally, our analyses indicate that 45 percent of American children reside in homes where the total family income is below 200 percent of poverty (including those in poor and deeply poor families). This estimate suggests that a vast proportion of our youth resides in homes confronting dayto-day financial pressures that may influence their growth and development.
Continued high child poverty in the aftermath of the Great Recession highlights the importance of the social safety net. The official poverty measure does include income from unemployment insurance and social security. Without unemployment insurance, Census Bureau estimates from the Current Population Survey (CPS) suggest an estimated 0.6 million more children would be poor, and without social security, an estimated 1.1 million additional children would live in poverty. The official poverty measure does not include the Supplemental Nutrition Assistance Program (SNAP) or the Earned Income Tax Credit (EITC). Census Bureau CPS estimates suggest that SNAP benefits essentially "lift" 1.7 million poor children out of poverty, and that the EITC raises family incomes above the poverty threshold for 3.1 million. ${ }^{10}$ In addition to the children lifted above the poverty line by these programs, millions more children benefit, as some of these programs offer aid to children in homes that are somewhat above the poverty line, and to children who are still poor even after the benefits. ${ }^{11}$ These programs are valuable in protecting children, and particularly young children, from the worst consequences of poverty.

\section{Data}

This analysis is based on estimates from the 2007, 2010, and 2011 American Community Survey. For more details or information, please refer to the U.S. Census American Community Survey. ${ }^{12}$ Tables were produced by aggregating information from detailed tables available on American FactFinder (http://factfinder2.census.gov/faces/nav/jsf/pages/ index.xhtml). These estimates are meant to give perspective on child poverty, but since they are based on survey data, caution must be used in comparing across years or places, as the margin of error may indicate that seemingly disparate numbers fall within reasonable sampling error. ${ }^{13}$ All differences highlighted in this brief and bolded in the tables are statistically significant $(p<0.05)$. 


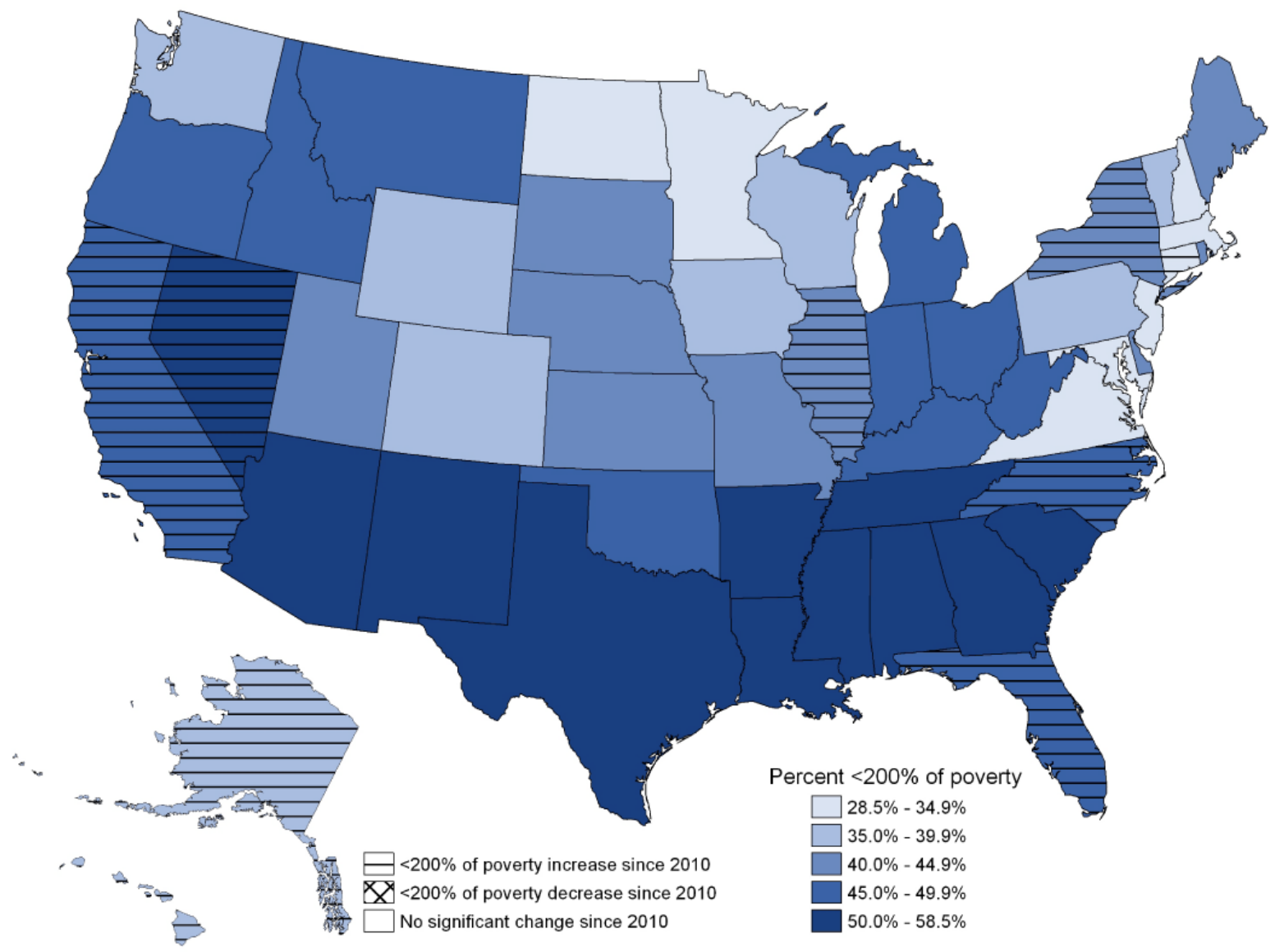


Appendix 1. Child POVERTy By STATE IN 2011

\begin{tabular}{|c|c|c|c|c|c|c|c|c|}
\hline & \multicolumn{8}{|c|}{2011 AMERICAN COMMUNITY SURVEY } \\
\hline & $\begin{array}{c}\text { Number } \\
\text { below } \\
\text { poverty }\end{array}$ & $\begin{array}{c}\text { Percent } \\
\text { below } \\
\text { poverty } \\
\end{array}$ & 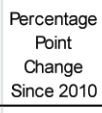 & $\begin{array}{c}\text { Percentage } \\
\text { Point } \\
\text { Change } \\
\text { Since 2007 } \\
\end{array}$ & $\begin{array}{c}\text { Number below } \\
200 \% \text { of } \\
\text { poverty }\end{array}$ & $\begin{array}{c}\text { Percent } \\
\text { below } \\
200 \% \text { of } \\
\text { poverty } \\
\end{array}$ & $\begin{array}{c}\text { Percentage } \\
\text { Point } \\
\text { Change } \\
\text { Since } 2010 \\
\end{array}$ & $\begin{array}{c}\text { Percentage } \\
\text { Point } \\
\text { Change } \\
\text { Since 2007 } \\
\end{array}$ \\
\hline United States & $16,400,000$ & 22.5 & 0.9 & 4.5 & $32,700,000$ & 45.0 & 0.9 & 5.6 \\
\hline Northeast & $2,257,692$ & 18.8 & 1.0 & 3.1 & $4,492,198$ & 37.4 & 1.2 & 4.2 \\
\hline Midwest & $3,353,167$ & 21.4 & 1.0 & 4.7 & $6,724,840$ & 42.9 & 0.6 & 5.9 \\
\hline South & $6,889,861$ & 25.1 & 0.9 & 4.5 & $13,300,000$ & 48.5 & 0.7 & 5.2 \\
\hline West & $3,885,780$ & 22.1 & 1.0 & 5.2 & $8,176,094$ & 46.4 & 1.2 & 6.7 \\
\hline Alabama & 306,973 & 27.6 & -0.1 & 3.3 & 571,251 & 51.4 & 0.8 & 4.9 \\
\hline Alaska & 26,941 & 14.5 & 1.6 & 3.1 & 73,057 & 39.5 & 7.9 & 8.8 \\
\hline Arizona & 434,950 & 27.2 & 2.8 & 7.1 & 838,987 & 52.5 & 1.0 & 7.7 \\
\hline Arkansas & 196,538 & 28.1 & 0.5 & 2.3 & 383,325 & 54.8 & 0.0 & 2.9 \\
\hline California & $2,084,522$ & 22.8 & 0.9 & 5.6 & $4,336,902$ & 47.5 & 1.3 & 6.8 \\
\hline Colorado & 217,049 & 17.9 & 0.5 & 1.6 & 483,292 & 39.8 & 1.2 & 4.7 \\
\hline Connectiout & 118,809 & 14.9 & 2.1 & 3.9 & 241,906 & 30.4 & 2.4 & 5.3 \\
\hline Delaware & 35,216 & 17.5 & -0.6 & 2.8 & 81,253 & 40.3 & 2.7 & 4.8 \\
\hline District of Columbia & 31,769 & 30.3 & -0.1 & 7.6 & 46,632 & 44.5 & -6.4 & -1.9 \\
\hline Florida & 980,002 & 24.9 & 1.4 & 7.8 & $1,964,026$ & 49.9 & 1.7 & 9.0 \\
\hline Georgia & 646,824 & 26.3 & 1.5 & 6.7 & $1,227,388$ & 50.0 & 1.2 & 7.9 \\
\hline Hawaii & 50,834 & 17.0 & 3.1 & 7.2 & 107,452 & 35.9 & 4.0 & 6.9 \\
\hline Idaho & 85,173 & 20.4 & 1.5 & 4.6 & 200,200 & 48.0 & -0.5 & 5.7 \\
\hline Illinois & 658,340 & 21.6 & 2.1 & 4.9 & $1,310,123$ & 42.9 & 2.0 & 6.5 \\
\hline Indiana & 360,859 & 23.0 & 1.3 & 5.8 & 710,347 & 45.4 & -1.2 & 7.0 \\
\hline lowa & 122,828 & 17.3 & 1.0 & 3.7 & 281,541 & 39.6 & 1.6 & 5.5 \\
\hline Kansas & 133,556 & 18.8 & 0.4 & 4.2 & 304,521 & 42.9 & 0.9 & 5.8 \\
\hline Kentucky & 275,394 & 27.4 & 1.2 & 3.5 & 494,481 & 49.2 & 0.1 & 2.5 \\
\hline Louisiana & 317,468 & 28.8 & 1.5 & 2.0 & 556,768 & 50.5 & 1.0 & 1.8 \\
\hline Maine & 49,561 & 18.8 & 1.0 & 3.5 & 112,893 & 42.9 & 1.8 & 4.5 \\
\hline Maryland & 178,725 & 13.5 & 0.5 & 3.0 & 400,914 & 30.3 & 0.6 & 4.9 \\
\hline Massachusets & 211,789 & 15.2 & 0.9 & 2.3 & 419,274 & 30.1 & 0.9 & 4.3 \\
\hline Michigan & 560,109 & 24.8 & 1.4 & 5.4 & $1,029,199$ & 45.6 & 0.4 & 6.6 \\
\hline Minnesota & 194,260 & 15.4 & 0.2 & 3.4 & 430,049 & 34.1 & 0.3 & 5.7 \\
\hline Mississippi & 235,727 & 31.8 & -0.7 & 2.5 & 433,076 & 58.5 & 1.1 & 4.6 \\
\hline Missouri & 306,038 & 22.1 & 1.2 & 4.4 & 622,428 & 44.9 & 0.1 & 4.5 \\
\hline Montana & 43,110 & 19.7 & -0.4 & 1.4 & 100,310 & 45.8 & 1.9 & 3.5 \\
\hline Nebraska & 81,943 & 18.1 & 0.0 & 3.2 & 183,750 & 40.7 & 0.3 & 3.3 \\
\hline Nevada & 144,440 & 22.1 & 0.1 & 6.8 & 327,755 & 50.1 & 4.0 & 13.0 \\
\hline New Hampshire & 33,031 & 12.0 & 1.9 & 3.2 & 78,749 & 28.5 & 2.3 & 6.0 \\
\hline New Jersey & 296,198 & 14.7 & 0.2 & 3.1 & 630,790 & 31.2 & 0.9 & 5.0 \\
\hline New Mexico & 157,383 & 30.7 & 0.7 & 5.3 & 293,791 & 57.3 & 2.0 & 5.9 \\
\hline New York & 950,921 & 22.6 & 1.3 & 3.1 & $1,796,972$ & 42.6 & 1.9 & 4.0 \\
\hline North Carolina & 579,725 & 25.6 & 0.7 & 6.1 & $1,123,132$ & 49.6 & 1.4 & 6.8 \\
\hline North Dakota & 21,827 & 14.6 & -1.6 & 1.2 & 51,611 & 34.6 & -0.8 & 1.9 \\
\hline Ohio & 640,884 & 24.2 & 0.9 & 5.7 & $1,204,451$ & 45.5 & 0.6 & 6.3 \\
\hline Oklahoma & 215,804 & 23.4 & -1.3 & 0.9 & 455,234 & 49.4 & -0.9 & 0.9 \\
\hline Oregon & 199,489 & 23.6 & 2.1 & 6.7 & 398,216 & 47.2 & -0.6 & 7.5 \\
\hline Pennsylvania & 531,993 & 19.6 & 0.5 & 3.2 & $1,080,096$ & 39.7 & 0.3 & 3.3 \\
\hline Rhode Island & 47,127 & 21.9 & 2.8 & 4.4 & 87,307 & 40.5 & 0.8 & 6.7 \\
\hline South Carolina & 296,759 & 27.8 & 1.7 & 6.9 & 553,768 & 51.9 & 1.5 & 7.5 \\
\hline South Dakota & 35,793 & 18.2 & 0.0 & 1.4 & 79,857 & 40.5 & -1.7 & -0.4 \\
\hline Tennessee & 385,931 & 26.3 & 0.6 & 3.3 & 739,536 & 50.3 & 0.2 & 4.6 \\
\hline Texas & $1,829,214$ & 26.6 & 0.9 & 3.4 & $3,507,480$ & 51.0 & 0.2 & 3.5 \\
\hline Utah & 138,024 & 15.9 & 0.1 & 4.9 & 352,125 & 40.5 & 0.1 & 6.0 \\
\hline Vermont & 18,263 & 14.9 & -1.8 & 2.5 & 44,211 & 36.1 & -2.9 & 3.8 \\
\hline Virginia & 280,115 & 15.3 & 0.8 & 2.3 & 614,718 & 33.6 & 0.4 & 3.9 \\
\hline Washington & 283,176 & 18.3 & 0.1 & 3.3 & 613,821 & 39.7 & 0.5 & 5.0 \\
\hline West Virginia & 97,677 & 25.8 & 0.4 & 3.1 & 184,347 & 48.8 & -0.2 & 1.8 \\
\hline Wisconsin & 236,730 & 18.2 & -0.8 & 3.8 & 516,963 & 39.8 & 0.1 & 6.0 \\
\hline Wyoming & 20,689 & 15.6 & 1.3 & 4.0 & 50,186 & 37.9 & -0.8 & 4.4 \\
\hline
\end{tabular}

Notes:

1. Data are based on 2011 American Community Survey estimates. For corresponding margins of error, refer to the U.S. Census American Community Survey.

2. Percentage point changes are based on unrounded poverty percentages and may differ slightly from those that would be obtained using ounded figures.

3. Bold font indicates statistically significant differences $(p<0.05)$. 


\section{E N D N O T E S}

1. U.S. Census Bureau, "Differences Between CPS ASEC and ACS," Fact Sheet (Washington, DC: U.S. Census Bureau, 2011). The Census Bureau recommends using the American Community Survey when comparing states or other geographic areas smaller than the national level. See also U.S. Census Bureau, "Income and Poverty Estimates: Guidance on When to Use Each Survey," News Release September 13 (Washington, DC: U.S. Census Bureau, 2011). Available at http://www.census.gov/newsroom/releases/pdf/incpovguidancedoc.pdf.

2. See "Poverty Thresholds for 2011," available at (http:// www.census.gov/hhes/www/poverty/data/threshld).

3. U.S. Census Bureau (2012, September 12), Income, Poverty and Health Insurance Coverage in the United States: 2011 Slide 22 [Webinar]. Retrieved from https://www.mymeetings.com/nc/join.

4. See, for example, Jeanne Brooks-Gunn, Greg J. Duncan, and Nancy Maritato, "Poor Families, Poor Outcomes: The Well-Being of Children and Youth," Chapter 1 in Consequences of Growing Up Poor, edited by Greg J. Duncan and Jeanne Brooks-Gunn (New York: Russell Sage Foundation, 1997). See also "Children at Risk: Consequences for School Readiness and Beyond," Rand Labor and Population Research Brief. Retrieved from http://www.rand.org/content/dam/ rand/pubs/research_briefs/2005/RAND_RB9144.pdf (2005).

5. Throughout this brief, we refer to "states." It should be noted that our usage here includes Washington, DC.

6. National Center for Children in Poverty (2009, September), Budgeting for Basic Needs: A Struggle for Working Families. Retrieved from http://www.nccp.org/publications/ pdf/text_858.pdf.

7. In the past, it has been possible to provide estimates of child poverty by place type for each state. Due to changes in the Census Bureau's presentation of data, this is no longer possible; instead, we examine variation by place type across regions and the nation. Although some states/places appear to have percentage point increases in poverty, those not in bold are not statistically distinguishable from zero.

8. See, for example, Jeanne Brooks-Gunn, Greg J. Duncan, and Nancy Maritato, "Poor Families, Poor Outcomes: The Well-Being of Children and Youth," Chapter 1 in Consequences of Growing Up Poor, edited by Greg J. Duncan and Jeanne Brooks-Gunn (New York: Russell Sage Foundation, 1997). See also "Children at Risk: Consequences for School Readiness and Beyond," Rand Labor and Population Research Brief. Retrieved from http://www.rand.org/content/dam/ rand/pubs/research_briefs/2005/RAND_RB9144.pdf (2005).
9. Judith Smith, Jeanne Brooks-Gunn, and Pamela Klebanov, "The Consequences of Living in Poverty on Young Children's Cognitive Development," in Greg Duncan and Jeanne Brooks-Gunn (eds), Consequences of Growing Up Poor (New York: Russell Sage Foundation, 1997) .

10. U.S. Census Bureau (2012, September 12). Income, Poverty and Health Insurance Coverage in the United States: 2011 Slide 22 [Webinar]. Retrieved from https://www.mymeetings.com/nc/join.

11. See, for example, First Focus (2011, December), New Report Finds Children Still Feeling Recession's Impact. Retrieved from http://www.firstfocus.net/news/ press_release/new-report-finds-children-still-feelingrecession\%E2\%80\%99s-impact; Julia B. Isaacs, "The Recession's Ongoing Impact on America's Children: Indicators of Children's Economic Well Being" (Washington, DC: Brookings Institution and First Focus, 2011); Center on Budget and Policy Priorities (2012, February), The Earned Income Tax. Retrieved from http://www.cbpp.org/files/policybasicseitc.pdf; Internal Revenue Service (2012), About EITC. Retrieved from http://www.eitc.irs.gov/central/abouteitc/; and Executive Office of the President (2011, December), Unemployment Insurance Extensions and Reforms in the American Jobs Act. Retrieved from http://www.whitehouse. gov/sites/default/files/ui_report_final.pdf.

12. See U.S. Census Bureau's American FactFinder. Available at http://factfinder2.census.gov/faces/nav/jsf/pages/index. xhtml.

13. See U.S. Census Bureau's American FactFinder. Available at http://factfinder2.census.gov/faces/nav/jsf/pages/index. xhtml.

\section{ABOUT THE AUTHORS}

Beth Mattingly is director of research on vulnerable families at the Carsey Institute and a research assistant professor of sociology at the University of New Hampshire (beth.mattingly@unh.edu).

Jessica A. Bean is a vulnerable families research scientist at the Carsey Institute (jessica.bean@unh.edu).

Andrew P. Schaefer is a doctoral student in sociology at the University of New Hampshire and a research assistant at the Carsey Institute (andrew.schaefer@unh.edu).

\section{A C K N O W L E D G M E N T S}

The authors thank Bruce Mallory, Curt Grimm, Amy Sterndale, Laurel Lloyd, Ken Johnson, Kristin Smith, William Meub, Barb Cook, and Jennifer Clayton at the Carsey Institute for their assistance, comments, and suggestions. 


\section{$\triangle$ UNIVERSITY - of NEW HAMPSHIRE}

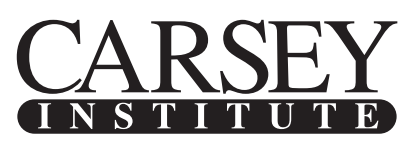

Building knowledge for families and communities

The Carsey Institute conducts policy research on vulnerable children, youth, and families and on sustainable community development. We give policy makers and practitioners timely, independent resources to effect change in their communities.

This work was supported by the Annie E. Casey Foundation, the W. K. Kellogg Foundation, and anonymous donors.

Huddleston Hall

73 Main Street

Durham, NH 03824

(603) $862-2821$

www.carseyinstitute.unh.edu 